\title{
PENGARUH KEMAJUAN TEKNOLOGI TERHADAP PERILAKU SOSIAL DAN LINGKUNGAN ANAK
}

\author{
Oktafia Dwi Sinta Uli B
}

(2010914220020@mhs.ulm.ac.id)

\author{
Program Studi Psikologi Universitas Lambung Mangkurat
}

\begin{abstract}
Abstrak
Penulisan artikel ini dilatarbelakangi oleh keprihatinan penulis terhadap perkembangan kemajuan teknologi zaman sekarang yang berpengaruh terhadap perilaku sosial dan lingkungan terkhususnya dalam perkembangan anak. Kemajuan teknologi ini yang termasuk dari bagian globalisasi dengan mudahnya masuk segala bentuk budaya dan ideologi dari luar. Banyak faktor yang yang menjadi penyebab terjadinya fenomena ini dan sekarang perhatian saya tertuju pada perkembangan anak termasuk dalam bermedia sosial hasil kemudahan kemajuan teknologi. Mungkin hal ini sudah banyak dikaji dengan beberapa asumsi ahli dan diteliti oleh para peneliti dan untuk penulisan saya ini berdasarkan kajian literatur dan observasi sederhana yang dimulai dari lingkungan disekitar saya. Banyaknya permasalahan dan pengaruh kemajuan teknologi dari yang positif sampai negatif beserta faktor penyebab-penyebabnya. Berdasarkan hal diatas anak-anak di era sekarang sudah terbiasa dengan teknologi dalam kehidupan sehari-hari sehingga dapat berpengaruh pada perilaku sosial anak serta lingkungannya. Serta bagaimana solusi agar kemajuan teknologi tidak berdampak buruk dan cara menyikapi dampak buruk yang mempengaruhi perilaku sosial dan lingkungan anak.
\end{abstract}

Kata kunci: kemajuan teknologi,perilaku sosial dan lingkungan,perkembangan anak

\begin{abstract}
Abstrak
The writing of this article is motivated by the author's concern about the development of technological advances today which affect social and environmental behavior, especially in child development. These technological advances, which are part of globalization, easily enter all forms of culture and ideology from outside. Many factors cause this phenomenon and now my attention is focused on child development, including in social media as a result of the ease of technological advancement. Maybe this has been widely studied with some expert assumptions and researched by researchers and for my writing this is based on literature review and simple observations starting from the environment around me. The number of problems and the influence of technological progress from positive to negative along with the factors that cause it. Based on the above, children in today's era are accustomed to technology in everyday life so that it can affect children's social behavior and their environment. As well as how the solutions so that technological advances do not have a bad impact and how to respond to the bad impacts that affect children's social and environmental behavior.
\end{abstract}

Keywords: technological progress, social and environmental behavior, child development 


\section{PENDAHULUAN}

Manusia merupakan makhluk ciptaan Tuhan yang dianugerahi akal dan budi, dari kelebihan itu manusia menggunakan nya untuk memenuhi kehidupannya salah satunya adalah memecahkan sebuah masalah yang ada dihidupnya agar kehidupan manusia dapat berjalan dengan aman, tentram dan juga nyaman. Dari situlah manusia menggunakan akal nya untuk menyelesaikan sebuah masalah dengan membuat solusi dengan mengembangkan teknologi menjadi suatu kemajuan dengan harapan konflik yang ada dapat diatasi dengan kemudahan.

Salah satunya menurut Marina Dwi Mayangsari dkk(2019) pada lingkungan anakanak, sudah bermunculan permainan modern seperti video game dan virtual game yang mengikis keberadaan permainan tradisional. Permainan modern umumnya dimainkan di dalam ruangan yang nyaman, seperti di rumah, di mall, maupun di warung internet (warnet) sehingga membuat anak-anak betah memainkannya berjam-jam.

Kemajuan teknologi adalah sesuatu yang tidak dapat kita hindari dalam kehidupan kita,dimana masa ini terus berkembang seiring dengan kemajuan ilmu pengetahuan yang menuntut kita untuk selaras dengan kemajuan ini. Kemajuan teknologi bukan hanya sekedar memberikan kenyamanan bagi para penggunanya namun pengaruh negatif yang terjadi pula beriringan masuk seiring dengan masuknya globalisasi. Dimana kemajuan teknologi tak akan lepas dari lingkup kehidupan masyarakat didunia. Awalnya kita menyambut baik akan perubahan ini namun kita tidak pernah menyangka pengaruh sangat luar biasa. Tak lepas pula kehidupan kita yang terus berjalan bagai roda yang terus berputar dari masa ke masa sampai pula pada globalisasi yang memasuki masa era revolusi industri atau 4.0 yang mana kita semua tahu bahwa "Revolusi Industri 4.0 secara fundamental mengakibatkan berubahnya cara manusia berpikir, hidup, dan berhubungan satu dengan yang lain. Era ini akan mendisrupsi berbagai aktivitas manusia dalam berbagai bidang, tidak hanya dalam bidang teknologi saja, namun juga bidang yang lain seperti ekonomi, sosial, dan politik "(Banu Prasetyo \& Umi Trisyanti,2014).

Kemajuan teknologi membuat semua nya menjadi mudah yaitu masuknya segala bentuk budaya dan ideologi dari luar. Hal ini berkaitan dengan perubahan transformasi nilainilai budaya yang semakin terkikis oleh dampak globalisasi sehingga masuknya hal tersebut membuat umat manusia tidak dapat membendung dan memfilter apa saja yang dapat diambil maupun yang tidak. Tuntutan zaman memang semakin kejam membuat umat manusia bersikap maju mundur,karena ketika kita tidak mengikuti zaman membuat kita semakin tertinggal jauh namun ketika kita mengikuti perkembangan zaman kita juga akan merasakan ketersediaan semua hal dalam sekejap.

Kemajuan teknologi membuat kita memahami istilah "semua ada dalam genggaman" dalam artian semua akses informasi kini bisa kita dapat kan dari mana saja hanya dengan teknologi dari belahan dunia manapun bisa kita akses dengan waktu yang singkat dan efisien. Menurut Charles Darwin (dalam Banu Prasetyo \& Umi Trisyanti,2014) perubahan yang terjadi tidak lagi memakan waktu ribuan tahun,namun membutuhkan waktu yang singkat saja. Seperti halnya dalam kondisi sekarang yang mana awalnya offline justru berubah semua kegiatan mengharuskan online yang memudahkan kita untuk tidak harus bertatap langsung namun dengan kemajuan teknologi kita dapat bertemu secara virtual untuk membendung adanya pertemuan secara langsung dan mengumpulkan banyak orang. Dunia sekarang dituntut untuk mengoptimalkan kemajuan teknologi untuk mengatasi permasalahan dunia,karena pada masa ini semua dialihkan kepada teknologi. Maka dari itu kemudahan yang ditawarkan tidak semertamerta selalu berdampak negatif namun dilain sisi ada banyak manfaat nya.

Teknologi Komunikasi dan Informasi adalah aplikasi pengetahuan dan keterampilan yang digunakan manusia dalam mengalirkan 
informasi atau pesan dengan tujuan untuk membantu menyelesaikan permasalahan manusia (aktivitas sosial) agar tercapai tujuan komunikasi (Daryanto,2018).

Kemajuan teknologi tidak sebatas bidang-bidang tertentu namun mencakup semua bidang seiring dengan kemajuan ilmu pengetahuan. Yang sering kita dengar yaitu kemajuan teknologi dapat memberikan kita kemudahan dari segala aspek termasuk dalam bidang komunikasi. Bidang komunikasi ini semakin hari semakin pesat perkembangannya dengan segala kemudahan berkomunikasi dengan segala tempat bisa kita jangkau dengan kemajuan teknologi. Kemajuan teknologi dalam bidang komunikasi salah satunya yaitu media sosial yang semakin hari semakin berkembang dengan cepat menghadirkan berbagai fitur untuk menarik perhatian penggunanya. Dari media sosial pun semua orang berlomba-lomba untuk menjadi sempurna dengan mengunggah apapun yang dirasa nya benar. Tak hanya itu saja menggunakan media sosial mengundang orang untuk memberika komentar, feedback, like, serta berlomba memberikan banyak informasi dalam sekejap dengan waktu yang singkat.

Media sosial jika dikaitkan dengan kehidupan kita banyak sekali manfaatnya namun banyak pula dampak buruk nya. Kita tidak bisa mengelakkan pengunaan media sosial dalam kehidupan kita, hampir jutaan pengguna didunia yang setiap hari nya mengakses media sosial. Menurut Nasrullah (dalam Mulawarman \& Aldila ,2017) hal tersebut merupakan sebuah tantangan sekaligus kenyataan yang tidak bisa dipungkiri.Kehadiran media sosial dan semakin berkembangnya jumlah pengguna dari hari ke hari memberikan fakta menarik betapa kekuatan internet bagi kehidupan.

Jenis-jenis nya pun semakin hari semakin beragam kemunculannya, yaitu Facebook, Instagram, Twitter, Askfm, Whatsapp, Line dan masih banyak lagi jenisnya. Dalam bermedia sosial pula semua hal atau informasi kita dapatkan tanpa adanya batasan/privasi yang jaringannya mencakup seluruh dunia dan mudah di jangkau siapa saja.
Anak-anak pada masa sekarang merupakan generasi yang lahir dan berkembang ditengah pesatnya kemajuan teknologi. Kemajuan teknologi dimasa sekarang membuat anak-anak pada masa ini bisa disebut dengan Generasi $\mathrm{Z}$ atau Net Generation, mempunyai karakteristik yang membuat mereka berbeda dengan generasi terdahulu (Agus,Nurul \& Nevi,2017). Pada masa ini semuanya sudah tersedia dan sangat memudahkan anak-anak yang lahir pada jaman ini, generasi ini pula menyukai kepraktisan untuk menyelesaikan dan mengambil suatu keputusan dengan cepat. Salah satu sumber yang selalu di andalkan adalah internet.Tak lepas pula dari kemajuan teknologi, perkembangan anak pun ikut terpengaruh akan pesatnya perkembangan jaman yang kian hari semakin cepat. Menurut Atik dkk (dalam Masithah, Soekirman, \& Drajat,2005) perkembangan anak merupakan proses yang kompleks, terbentuk dari potensi diri anak yang bersangkutan dan lingkungan sekitarnya. Lingkungan pertama dan utama yang berpengaruh terhadap perkembangan anak adalah lingkungan keluarga, dimana orang tua merupakan sosok yang paling berperan. Orang tua harus mampu menciptakan kondisi lingkungan keluarga menjadi lingkungan yang kondusif bagi kencenderungan tingkah laku melindungi dan mensejahterakan anak.

Kemajuan teknologi sangat mempengaruhi tumbuh kembang anak apalagi ketika pesat nya perkembangan zaman membuat perkembangan anak semakin terus maju tanpa henti dan pastinya semakin berbeda dari zaman sebelumnya. Otomatis semua perkembangan anak juga mengikuti kemajuan teknologi. Peran orang tua pula tak lepas dalam mengasuh anaknya di era yang semakin pesat ini. Orang tua pula dituntut untuk cepat tanggap beradaptasi dengan keadaan, sehingga proses perkembangan anak pula akan sejalan dengan kemajuan teknologi. Maka dari itu manusia tidak pernah statis. Semenjak pembuahan hingga ajal selalu terjadi perubahan, baik dalam kemampuan fisik maupun kemampuan psikologis (Hurlock,2013). Mulai dari masa bayi sampai dewasa, kemajuan teknologi akan selalu berubah tidak akan pernah berhenti untuk menghasilkan inovasi. Maka dari terbentuknya 
suatu kepribadian anak pada masa perkembangan nya perlu perhatian khusus.

Adapun perubahan yang terjadi pasti akan berdampak dalam perilaku sosial dan lingkungannya. Hubungan keduanya saling berkesinambungan dimana pola asuh orang tua merupakan salah satu indikasi bagi anak dalam mengontrol perilakunya di dalam kehidupan bermasyarakat. Orang tua memiliki pengaruh yang sangat besar dalam membentuk perilaku anak (Tria dan Made,2016)

Kemudian, B.F. Skinner $(1953,1957,1974)$ membantu mengubah fokus behaviorisme melalui percobaan yang dinamakan "operant behavior" dan "reinforcement". Yang dimaksud dengan "operant condition" adalah setiap perilaku yang beroperasi dalam suatu lingkungan dengan cara tertentu, lalu memunculkan akibat atau perubahan dalam lingkungan tersebut.

Anak akan menyesuaikan perilaku nya sesuai pola asuh orang tua dan lingkungan keluarganya. Apa yang diperolehnya pada masa perkembangan itu akan berdampak pada perilaku sosialnya. Menurut Rusli Ibrahim (2011) dalam Didi Budiman (2012) perilaku sosial adalah suasana saling ketergantungan yang merupakan keharusan untuk menjamin keberadaan manusia. Dimana setiap individu manusia akan saling membutuhkan satu sama lain dalam kehidupannya,dimana setiap hubungan yang terjadi akan saling menjadi hubungan timbal balik. Perilaku sosial pula merupakan respon yang terjadi dengan cara yang berbeda setiap individunya terhadap situasi lingkungannya dimana ia berada. Dari situ akan nampak dampak dan perubahan yang terjadi atas lingkungan. Lingkungan pula merupakan tempat atau wadah untuk tumbuh dan berkembang. Yang mana dari lingkungan lah kita belajar dan mengerti hal baru.Sehingga lingkungan merupakan pendorong kemajuan teknologi terjadi. Pada lingkungan pula kita dapat mengaplikasikan pengaruh kemajuan teknologi tersebut. Dan semua kembali ke lingkungan masing-masing dengan dilatarbelakangi perilaku sosialnya. Maka dari itu kita perlu memahami apa saja faktor-faktor yang mempengaruhi kemajuan teknologi terhadap perilaku sosial dan lingkungannya. Berdasarkan perilaku sosial dan lingkungannya serta peran orang tua dalam perkembangan anaknya terhadap kemajuan teknologi.

\section{METODE}

Berdasarkan tujuan penelitian ini,maka metode yang digunakan adalah studi pustaka (literature review) yaitu menggunakan metode studi literatur dengan mereview sebanyak kurang lebih 10 jurnal yang berkaitan dengan kemajuan teknologi terhadap perilaku sosial dan lingkungan anak serta jenis teknologi itu sendiri . Jurnal yang direview 15 tahun terakhir. Dengan sistematis perumusan masalah yang terjadi dan merujuk pada kajian jurnal yang terdapat masalah tersebut.

\section{HASIL DAN PEMBAHASAN}

Pertama untuk mengetahui tujuan dari penelitian studi literatur ini kita perlu memahami pokok permasalahan yang ada dalam topik ini. Dengan berbagai sumber kajian dan observasi pengalaman pun dilakukan agar sesuai tujuan yang hendak dicapai. Mulai dari pembahasan masalah sampai titik temu solusi dari permasalahan tersebut.

Generasi anak zaman sekarang dimana mereka semua lahir dan tumbuh dalam buaian teknologi informasi yang sangat canggih. Perilaku sosial anak pun menjadi perhatian khusus pada masa sekarang. Penulis menemukan banyak tindakan amoral anak usia awal yang disebabkan perkembangan teknologi sebagai faktor penyebab terbesarnya.

Pengaruh kemajuan teknologi terhadap perilaku sosial dan lingkungan anak sangat banyak terjadi,bisa pengaruh buruk maupun pengaruh yang baik terhadap perkembangan anak. Berbagai faktor yang menjadi penyebab mengapa kemajuan teknologi dapat mempengaruhi perilaku sosial dan lingkungan anak. Yang pertama kemajuan teknologi menawarkan segala kemudahan yang ada dan semua tersaji secara instan,salah satunya adalah dalam bidang teknologi komunikasi dan informasi. Dari bidang ini pengaruh buruk yang paling besar muncul,dimana orang tua lah yang dapat memberikan contoh dengan memilah dan memilih apa yang pantas di ajarkan untuk anaknya maka perilaku sosial mereka akan 
dapat dikendalikan. Ketika lingkungan nya memberikan respon energi positif terhadap penggunaan kemajuan teknologi dan akan seiras dengan respon yang diberikan dari terbentuknya perilaku sosial anak itu sendiri.

Yang kedua seiring perkembangan pesat kemajuan teknologi ini , masuk pula berbagai tantangan baru yaitu budaya dan ideologi yang berbeda,penggunaan gadget yang berlebihan yang dapat merusak otak anak,serta kurangnya sosialisasi terhadap lingkungan,dimana ketika kemajuan teknologi semakin pesat tak akan bisa kita cegah masuknya hal-hal seperti itu yang mempengaruhi perilaku sosial anak. Apalagi saat tidak adanya pengawasan yang ketat terhadap anak, maka besar pengaruh nya terhadap perilaku, gaya hidup, mental, dan kehidupan sosialnya yang terkadang melanggar norma dan aturan. Kita tidak bisa pungkiri bahwa setiap orang tua tidak selalu 24 jam dapat mengawasi tumbuh kembang anaknya,mulai dari apa yang ia pelajari dan ia tonton setiap harinya. Tetapi peran serta pengasuhan orang tua lah yang paling utama untuk mengenalkan teknologi,karena ketika anak berada dalam kondisi yang positif maka sikap dan tingkah laku sosialnya akan ikut serta dalam lingkup yang positif pula. Menurut Padmonodewo (2003:1) dalam Jurnal Tria dan Made (2016) perilaku sosial adalah tingkah laku anak untuk menyesuaikan diri dengan aturan-aturan yang berlaku didialam masyarakat di mana anak berada. Maka dari itu pengaruh kemajuan teknologi sangat besar dampak nya pada kehidupan bersosial anak.

Kemudian bagaimana cara nya agar kemajuan teknologi tidak membawa dampak buruk pada anak? Pertanyaan seperti ini sangat sering sekali kita temui sebagai permasalahan yang klise namun sangat susah untuk dipecahkan.Berbagai macam ahli berpendapat mengenai hal tersebut,tapi nyatanya nya susah untuk terealisasi.Determinasi kemajuan teknologi terhadap anak bisa mempengaruhi pergaulan serta perilakunya,yang mana banyak sekali macam-macam jenis determinasi teknologi bisa melalui internet, media sosial dan lainnya.

Dimana teknologi juga membentuk individu bagaimana berpikir,bertindak dan berperilaku dalam suatu lingkungan dimasyarakat. Selanjutnya orang tua harus pintar-pintar mengenalkan teknologi agar nantinya dapat berdampak positif bagi anak. Karena ketika anak dibimbing untuk mengenali potensinya dengan proses menstimulus anak dengan pengetahuan teknologi yang benar sesuai usianya. Pola asuh orang tua sangat mempengaruhi bagaimana nantinya kemajuan itu akan berdampak,sesuaikan dengan kondisi keluarga serta memberikan pendekatan secara mendidik dengan bijak,kemudian tidak hanya menceramahi tetapi memberikan tindakan sebuah contoh,agar anak dapat mengerti dengan baik. Dan tidak lupa juga sesuaikan usianya untuk mengenali sebuah teknologi, tidak membebaskan anak untuk mengenali teknologi diluar kebijakan, sesuaikan potensi yang dimiliki anak agar dapat menunjang kreativitas dengan berbagai teknologi.

Pengaruh buruk akibat kemajuan teknologi terhadap anak yaitu: Anak akan menjadi ketergantungan akan teknologi, contohnya saja dalam pendidikan ketika anak memiliki PR matematika. Pastinya ia akan langsung mencari di mbah google tanpa dimengerti terlebih dahulu apa yang dimaksud oleh soalnya. Sama halnya pada anak balita yang sudah dibiasakan orang tua ketika anaknya menanggis, pastinya akan diberikan hiburan dari tontonan di handphone nya. Lama kelamaan kebiasaan seperti ini membuat si anak menjadi manja dan terbuai dengan tontonan nya dari pada lingkungan sekitarnya.

Kemudian juga pada pergaulan dunia maya salah satunya media sosial yang membuat anak-anak yang seharusnya belum cukup umur untuk mengakses itu semua dan terlanjur masuk dalam pergaulan yang tidak baik. Membuatnya dapat mengakses situs apa saja tanpa filter dan membuat pergaulan anak menjadi negatif. Ketergantungan akan media sosial pula dapat membahayakan kondisi mental dan perilaku nya yang belum siap menerima hal-hal yang belum seharusnya mereka tahu. Peran orang tua pula berhubungan dengan tingkat kepercayaan diri anak,ketika anak terlalu bergantung pada teknologi mereka cenderung malu dan kurang bersosialisasi dengan lingkungannya sebagaimana seharusnya anak seumurannya. Tindakan amoral yang terjadi pun banyak membuat keresahan dalam lingkungan sosial maupun keluarga. 
Salah satu contohnya ketika seorang anak diberi tahu oleh orang tua nya untuk tidak berkata kasar,karena pengaruh teknologi yang menyebabkan virus bahasa baru atau bahasa gaul yang terucap oleh anak kecil dan sudah menjadi kebiasaan. Serta adanya perilaku menyimpang anak,oleh karena ada nya suatu penyimpangan terhadap moral,maka lingkungan anak ikut berantakan pula.Adanya peran pendidikan dan orang tua yang sangat mempengaruhi perilaku sosial anak dalam menyikapi dengan baik kemajuan teknologi yang terjadi saat ini. Ketika keduanya saling melengkapi dalam pengawasan dan pengajaran serta mengarahkan anak akan menimbulkan pengaruh yang positif dan berdampak pula pada lingkungan yang positif pula. Serta berkurangnya kemerosotan moral akibat kemajuan teknologi.

Dalam jurnal "Literasi Budaya Lokal Sebagai Wahana Edukasi di Era Milenial" didalam terdapat suatu upaya yang digalakkan akibat pengaruh kemajuan teknologi yaitu literasi budaya lokal melalui sistem pendidikan yang menekan kan pada proses pemahaman siswa dengan sikap kritis dan kesadaran akan ketertinggalan. Perubahan kehidupan sosial berjalan lebih cepat dibanding dengan pendidikan,maka dari itu perlunya minat literasi akan budaya dalam praktik pembelajaran disekolah sehingga budaya tidak akan tenggelam oleh arus kemajuan teknologi yang pesat Mutiani, M. (2018).

Selanjutnya tidak lepas dari peran asuh orang tua dan juga pendidikan. Semuanya akan sejalan ketika anak dapat mengkondisikan semua pengajaran dan pengimplementasi dalam kehidupannya. Mulai dari awal pengenalan sampai akhirnya mendapati manfaat yang baik dari kemajuan teknologi tersebut. Kemudahan yang terjadi dapat membuat kondisi kehidupan dan kepribadian anak menjadi terarah dan tidak menyimpang jauh. Sehingga tingkat kemunduran moralitas pada anak terhadap perilaku sosialnya serta lingkungannya dapat berkurang. Maka semua permasalahan klise yang terjadi dalam arus kemajuan teknologi ini dapat ditekan dan kesadaran akan pentingnya menanamkan karakter dalam pendidikan dengan literasi budaya serta penguatan karakter sosial dan agama disekolah dan lingkungan keluarga.
Pemahaman pola asuh orang tua pun menjadi titik utama menyikapi pengaruh buruk yang telah terjadi,karena ketika perkembangan anak dibentengi dengan pola asuh sosial seperti membatasi penggunaan teknologi yang terlalu lama,mengisi waktu luang dengan permainan tradisional,mendampingi serta mengawasi saat menggunakan teknologi, melarang serta memberikan pemahaman mana yang boleh dan tidak boleh dan pemahaman sex edukasi serta agama yang baik maka karakter yang terbentuk akan sejalan dengan manfaat yang didapat dari arus kemajuan teknologi (Ripyatul Ansyah, Jehan Safitri, Rika Vira Zwagery,2019).

Pengaruh kemajuan teknologi yang lainnya yaitu:

\begin{tabular}{|c|c|}
\hline Dampak Negatif & Dampak positif \\
\hline $\begin{array}{c}\text { Dapat terjerumus } \\
\text { pergaulan yang buruk } \\
\text { melalui situs-situs } \\
\text { internet }\end{array}$ & $\begin{array}{c}\text { Dapat mengenali dunia } \\
\text { secara cepat dan } \\
\text { memperluas wawasan }\end{array}$ \\
\hline $\begin{array}{c}\text { Mengurangi hubungan } \\
\text { dan keterampilan } \\
\text { bersosial terhadap } \\
\text { lingkungan }\end{array}$ & $\begin{array}{c}\text { Menguasai bahasa asing } \\
\text { dengan cepat }\end{array}$ \\
\hline $\begin{array}{c}\text { Ketergantungan akan } \\
\text { media sosial }\end{array}$ & $\begin{array}{c}\text { Meningkatkan kualitas } \\
\text { dan fasilitas } \\
\text { pembelajaran anak }\end{array}$ \\
\hline $\begin{array}{c}\text { Malas bersosialisasi } \\
\text { bersama orang lain }\end{array}$ & $\begin{array}{c}\text { Membentuk } \\
\text { kreativitas minat dan } \\
\text { bakat }\end{array}$ \\
\hline $\begin{array}{c}\text { Mengikuti budaya } \\
\text { kebarat-baratan dan } \\
\text { menggunakan bahasa } \\
\text { yang tidak sesuai }\end{array}$ & $\begin{array}{c}\text { Membuat anak } \\
\text { menjadi jago dalam } \\
\text { teknologi salah } \\
\text { satunya komunikasi }\end{array}$ \\
\hline
\end{tabular}

\section{KESIMPULAN}

Kemajuan teknologi yang merupakan tantangan besar untuk mempengaruhi perilaku sosial dan lingkungan anak. Tantangan ini dapat mempengaruhi anak dari pengaruh positif sampai pengaruh negatif yang terjadi. Kemerosotan nilai moral yang diakibatkan pengaruh negatif turut menjadi suatu keprihatinan terhadap anak. Maka dari itu peran 
orang tua dan penanaman pendidikan karakter menjadi suatu tameng dalam menyikapi pengaruh buruk dari kemajuan teknologi tersebut. Perilaku sosial anak pun dapat di arahkan menjadi lebih baik sesuai masa perkembangannya dan pemanfaatan teknologi bagi pengembangan bakat dan minat anak. Semua solusi yang sudah disebutkan diatas diharapkan dapat menekan permasalahan moral dan sosial yang terjadi. Dengan kesadaran dini oleh orang tua akan pentingnya peran orang tua dan pendidikan dalam penekanan masalah tersebut dapat mengurangi dampak buruk yang terjadi pada anak yang merupakan generasi pemimpin masa depan.

\section{DAFTAR PUSTAKA}

Prasetyo, B., \& Trisyanti, U. (2018). Revolusi Industri 4.0 dan Tantangan Perubahan Sosial. IPTEK Journal of Proceedings Series, (5), 22-27.

Mulawarman, M., \& Nurfitri, A. D. (2017). Perilaku Pengguna Media Sosial beserta Implikasinya Ditinjau dari Perspektif Psikologi Sosial Terapan. Buletin Psikologi, 25(1), 36-44.

Setiawan, D. (2018). Dampak perkembangan teknologi informasi dan komunikasi terhadap budaya. JURNAL SIMBOLIKA: Research and Learning in Communication Study, 4(1), 62-72.

Mutiani. (2017). IPS dan Pendidikan Lingkungan: Urgensi Pengembangan Sikap Kesadaran Lingkungan Peserta Didik. SOSIO DIDAKTIKA: Social Science Education Journal, 4(1), 2017, 45-53.

Ansyah, R., Safitri, J., \& Zwagery, R. V. (2020). HUBUNGAN PERSEPSI COPARENTING DENGAN INTERAKSI TEMAN SEBAYA PADA SISWA SEKOLAH MENENGAH PERTAMA NEGERI 2 MARTAPURA. Kognisia prodi Psikologi FK ULM, 2(1), 15-25.

Amini, M., Mayangsari, M. D., \& Zwagery, R. V. (2020). Hubungan antara Kemandirian Belajar dengan Komitmen
Tugas pada Mahasiswa Program Studi Psikologi. Jurnal Kognisia: Jurnal Mahasiswa Psikologi Online, 2(2), 149152.

Abbas, E. W. (2020). Ersis Writing Theory: Cara Mudah Menulis.

Hurlock, E. B. (2003). Psikologi Perkembangan Suatu Pendekatan Sepanjang Rentang Kehidupan. Jakarta: Erlangga.

Mutiani, M. (2018). Literasi Budaya Lokal Sebagai Wahana Edukasi Di Era Milenial.

Novasari, T. (2016). Pengaruh Pola Asuh Orang Tua terhadap Perilaku Sosial (Studi pada Siswa Kelas X Smkn 5 Surabaya). Kajian Moral dan Kewarganegaraan, 4(3).

Budiman, D. (2012). Bahan Ajar MK psikologi dalan penjas PGSD.

Mayangsari, M. D., Nurrachmah, D., Zwagery, R. V., Safitri, J., \& Rahmiyati, R. (2019, May). Program "Baper Mental"(Back to permainan tradisional) sebagai upaya pengembangan promosi wisata edukasi di Kampung Pelangi. In $P R O$ SEJAHTERA (Prosiding Seminar Nasional Pengabdian kepada Masyarakat) (Vol. 1, No. 1). 